Proc. Indian Acad. Sci. (Earth Planct. Sci.), Vol. 95, No. 3, November 1986, pp. 397-407.

(C) Printed in India.

\title{
Natural radioactivity distribution studies in Trivandrum district, Kerala, India
}

\author{
G K RAJU, JOHN MATHAI, G R RAVINDRA KUMAR and \\ N G K NAIR \\ Centre for Earth Science Studies, Trivandrum 695031, India
}

MS received 2 May 1985; revised 18 Octoher 1985

\begin{abstract}
The distribution pattern of radioactive minerals in Trivandrum district of Kerala has been investigated. The surface radioactivity was measured employing a jeep-mounted four-channel gamma-ray spectrometer coupled to a high volume Na I (TI) crystal detector. The distribution of radioactivity has been correlated with the corresponding litho-units and major structures of the study area. The total countrate from sedimentaries including beach sands and pegmatite rich zones $(\sim 3,500)$ CPS $)$ are significantly higher than that of the laterites and gneisses which are substantiated by laboratory studies.
\end{abstract}

Keywords. Radiometric survey; jeep mounted gamma ray spectrometer; radioactive elements; Compton stripping coefficients; monazite, tectonic lineaments.

\section{Introduction}

The southwest coast of India is known to be one of the five major natural radioactive zones in the world. Several localities rich in radioactive minerals have been identified along the coastal regions of India, particularly in Kerala and Tamil Nadu (Brown and Dey 1975). The beach sands contain monazite, ilmenite, rutile, sillimanite, garnet and zircon abundantly. These heavy minerals are known to have been transported from the high ranges of Western Ghats through rivers to the coast (Mahadevan et al 1958; Aswathanarayana 1964). However, detailed work on these placer deposits and their bearing on the geology is lacking. The radiation dose rate and the effect on the environment have been studied in this area (Bharatwal and Vaze 1958; Ganguly et al 1964; Sunta et al 1971; Kulkarni et al 1974). In view of the geological significance a systematic radiometric study coupled with geological investigations was carried out in Trivandrum district covering the coastal plains, the midland and the highland areas (Western Ghats). These studies are aimed at identifying anomalous radioactive pockets and source regions and their bearing on the geological problems. Radiometric surveys in the polyphasedly deformed gneiss-granulite terrain of Kerala with enclaves of metasediments, numerous belts of pegmatite and extensive fault/shear zones are of utmost interest. The radiometric response can show characters attributable to recognizable events such as potash metasomatism which give an empirical pattern correlatable with lithology (Sherrington 1977) and delineate zones rich in radioactive minerals (Lovborg et al 1976, 1979; Wormald and Clayton 1976). Although airborne radiometric investigations have been successfully employed elsewhere for geological mapping and identification of anomalous radioactive zones (Darnley 1973; Grasty 1975; Foote 
and Humphery 1976) jeep-borne radiometric surveys have not been carried out in many regions. This paper presents the natural surface radioactivity measurements in Trivandrum district, Kerala (figure 1) employing a jeep-borne gamma-ray spectrometer. Laboratory analyses of the representative samples from the anomalous zones have also been carried out to substantiate the field measurements. The distribution pattern of radioactivity and the possible correlation with geological features are discussed.

\section{Instruments and methods}

A Scintrex type four-channel gamma-ray spectrometer (GAD-6), a high volume sensor of $1853 \mathrm{cc} \mathrm{Na}$ I (T1) crystal (GSA-61S) and a strip-chart recorder (RCM-4)

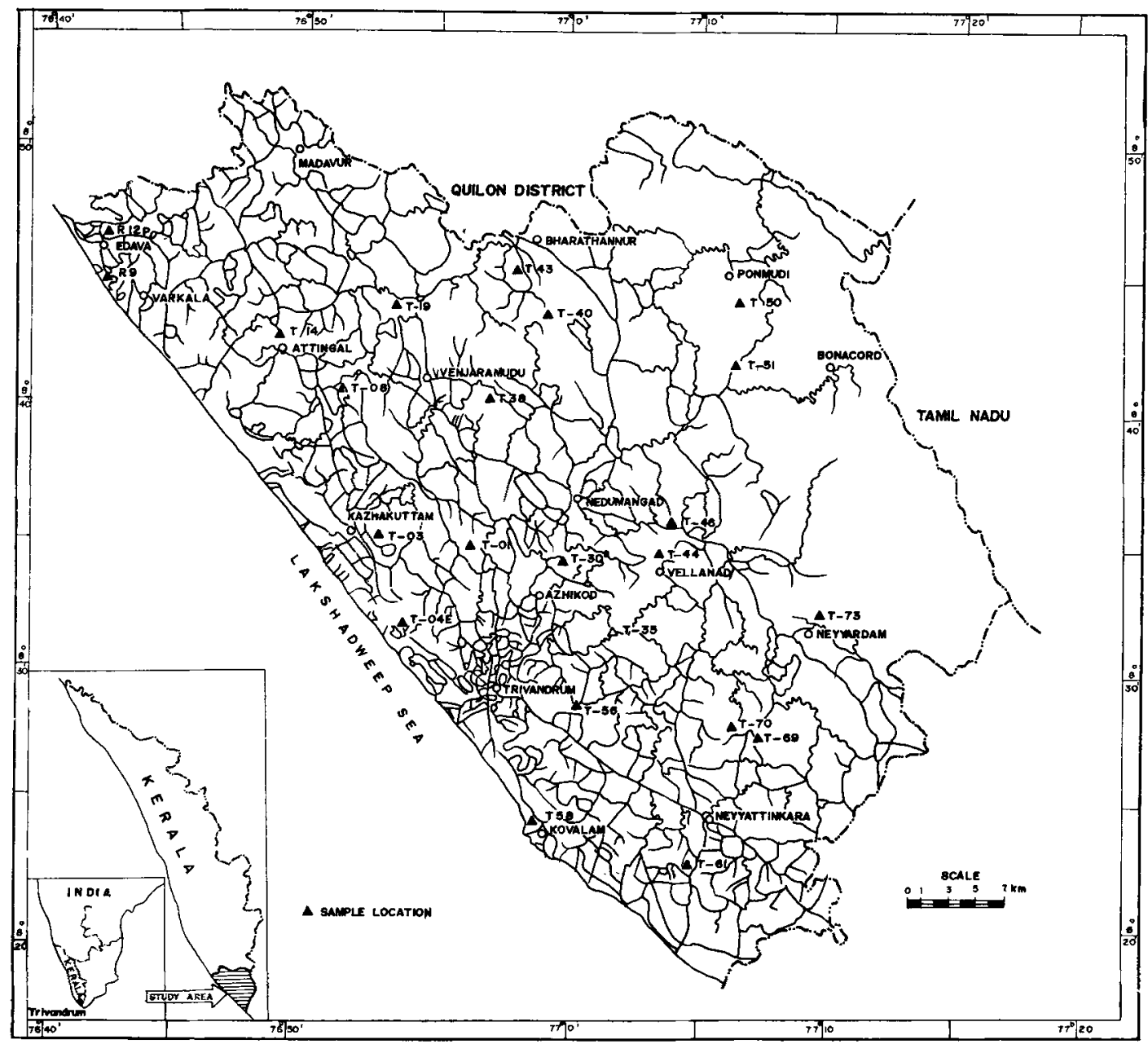

Figure 1. Map showing the study area, jeep traverse network, and locations of the samples. 
were used for the survey operations. These instruments were specially designed for radiometric survey to measure individual elemental distribution in soils and rocks (Lovborg et al 1979; IAEA 1979). The sensor, mounted on top of the Landrover (jeep) at a height of about $3 \mathrm{~m}$ from the ground, enabled scanning an area of about 15 to $20 \mathrm{~m}$ radius of the ground effectively. However, since the detector was not shielded, it may be sensitive to the radioactivity from all directions up to a few hundred meters. Precautionary measures were taken to protect the sensor from jerks of the vehicle, temperature variation and moisture. Energy was calibrated once in a week using a $\mathrm{ThO}_{2}$ calibration source of intensity 2.02 microcuries to ensure accurate measurements.

The spectrometer is a battery-operated spectral stabilized gamma-ray analyser which anaiyzes the responses from the sensor according to the four calibrated energy windows at $2.62 \mathrm{MeV}$ line for thorium, $1.76 \mathrm{MeV}$ line for uranium, 1.46 $\mathrm{MeV}$ line for potassium and $0.4 \mathrm{MeV}$ to $2.77 \mathrm{MeV}$ for total radioactivity. The output from these energy windows was fed to the corresponding pointers of the strip-chart recorder. The movement of the chart was synchronized with vehicle speed to obtain an authentic record of the radiometric data with respect to the distance. The pointers of the chart were calibrated by adjusting the amplifier gain of the chart-recorder using the digital display of the spectrometer. The countrate obtained in the field was corrected for Compton effect and recorded on the chart. The Compton correction factors were calculated in the laboratory conditions and the spectrometer is set accordingly. To eliminate the Compton effect on the energy spectra of the natural gamma radiation, stripping coefficients $\alpha, \beta$ and $\gamma$ were determined using pure series (equilibrium sources) of thorium and uranium standards and set to the inbuilt stripping ratio switches of the spectrometer. For this purpose, a thorium source of 2.02 microcuries and uranium source of 1.15 microcuries of $5.5 \mathrm{~cm}$ dia each are used to calculate the stripping coefficients. As these standards were small in size, they were kept close to the detector to achieve reasonable counts for calculation of such coefficents. The stripping factors obtained in this way were compared with the standard values given in the manual. The relation between element concentration and countrate is given in table 1 .

Since the survey operations were confined to motorable roads, all the road junctions were numbered on the map as well as on the chart while recording the radiometric data. The vehicle was run at a constant speed of about $20 \mathrm{~km} / \mathrm{hr}$ and every $100 \mathrm{~m}$ distance was marked on to the chart by an autopuncher. When in operation the accumulated counts for every $3 \mathrm{sec}$ were recorded on the chart through pointers coupled to the output of the spectrometer. The recorded data on the chart was cross-checked with digital display from time to time and also in places

Table 1. Element concentration - Jeep-borne countrate correlation.

\begin{tabular}{cccccccc}
\hline $\begin{array}{c}\text { Sensor } \\
\text { (volume } \\
\text { in cc) }\end{array}$ & $\begin{array}{c}\text { Thorium } \\
\text { (ppm/count/ } \\
\mathrm{sec})\end{array}$ & $\begin{array}{c}\text { Uranium } \\
\text { (ppm/count/ } \\
\mathrm{sec})\end{array}$ & $\begin{array}{c}\text { Potassium } \\
\text { (ppm/count/ } \\
\text { sec }\end{array}$ & \multicolumn{3}{c}{$\begin{array}{c}\text { Stripping } \\
\text { Coefficients. }\end{array}$} \\
\hline $\begin{array}{c}\text { GSA-61S } \\
(1853)\end{array}$ & 2.7 & 1.37 & 0.13 & 0.5 & 0.49 & 0.67 \\
\hline
\end{tabular}


where higher countrate is observed. The topographical features are noted to relate their influence on the countrate. Since the measurements are confined to a relatively thin surface layer of about $30-35 \mathrm{~cm}$ (Darnley 1975) the recorded radioactivity in each channel for thorium, uranium, potassium and total counts were alluvium or drift. Hence no correlation gradiation was attempted with underlying bed rock in areas covered by transported material.

The data recorded in graphical form in the charts were decoded by averaging the counts for every $100 \mathrm{~m}$ distance. For easy reduction of the data, levels of radioactivity is each channel for thorium, uranium, potassium and total counts were chosen. Their values were plotted on the map and contoured. While contouring, several parameters such as field radioactivity, surrounding rock units, soil condition geometrical factors etc were considered. Representative samples from the anomalous radioactive zones were collected with the help of a potable $5 \times 5 \mathrm{~cm}$ $\mathrm{NaI}$ (T1) crystal detector. These samples were analyzed in laboratory to confirm the field data. The samples were powdered to 100 mesh size and analyzed using a gamma-ray spectrometer (GRS 23, ECIL) in the laboratory. The samples weighing $200 \mathrm{~g}$ were sealed in plastic containers and analyzed with counting time varying between 1000 and $2000 \mathrm{sec}$ depending on the activity level present. The counts recorded for each element were converted to their respective concentration levels using standards of equal amount (Adams and Gasparini 1979). The radioelement concentrations are given in table 2 . The results are comparable with field observations.

Table 2. Spectrometric analyses of radioelement concentrations of selected samples.

\begin{tabular}{|c|c|c|c|c|}
\hline $\begin{array}{c}\text { Sample } \\
\text { No. }\end{array}$ & Sample description & $\mathrm{K} \%$ & $\begin{array}{c}\mathrm{e}^{U} \\
(\mathrm{ppm})\end{array}$ & $\begin{array}{c}\mathrm{e}^{\mathrm{Th}} \\
(\mathrm{ppm})\end{array}$ \\
\hline $\mathrm{T}-\mathbf{3 0}$ & Quartzo feldspathicgneiss & $1 \cdot 1$ & 3 & 82 \\
\hline $\mathrm{T}-38$ & Garnet biotitegneiss & $1 \cdot 5$ & 4 & 80 \\
\hline $\mathrm{T}-43$ & Quartzo feldspathicgneiss & $1 \cdot 4$ & 8 & 79 \\
\hline $\mathrm{T}-44$ & Graphite schist & - & 256 & 1282 \\
\hline $\mathrm{T}-50$ & Garnet sillimanitegneiss & 0.6 & 19 & 25 \\
\hline$T-69$ & Garnet sillimanitegneiss & 0.9 & 11 & 23 \\
\hline $\mathrm{R} 12-\mathrm{P}$ & Sandstone rich in heavy minerals & - & 362 & 8266 \\
\hline $\mathrm{T}-03$ & Surface soil rich in heavy minerals & - & 658 & 3984 \\
\hline$T-12$ & Soil upto $1 \mathrm{~m}$ depth & 0.7 & 28 & 182 \\
\hline$T-61$ & Surface soil & - & 792 & 7922 \\
\hline $\mathrm{T}-01$ & Stream sediment & - & 17 & 117 \\
\hline$T-04 \mathrm{E}$ & Sediment rich in heavy minerals & - & 1268 & 6085 \\
\hline $\mathrm{T}-08$ & Stream sediment & $1 \cdot 7$ & 10 & 68 \\
\hline $\mathrm{T}-14$ & Stream sediment & - & 109 & 397 \\
\hline $\mathrm{T}-19$ & Stream sediment & - & 121 & 456 \\
\hline $\mathrm{T}-35$ & Stream sediment & - & 101 & 451 \\
\hline $\mathrm{T}-40$ & Stream sediment & - & 667 & 2947 \\
\hline $\mathrm{T}-46$ & Stream sediment & - & 86 & 267 \\
\hline $\mathrm{T}-51$ & Stream sediment & - & 52 & 263 \\
\hline $\mathrm{T}-56$ & Stream sediment & - & 61 & 276 \\
\hline $\mathrm{T}-70$ & Stream sediment & - & 265 & 1961 \\
\hline $\mathrm{T}-73$ & Stream sediment & $1 \cdot 2$ & 297 & 977 \\
\hline $\mathrm{R}-09$ & Beach placer & - & 1412 & 21999 \\
\hline $\mathrm{T}-58$ & Beach placer & - & 507 & 3049 \\
\hline
\end{tabular}




\section{Geological set-up}

The study area viz Trivandrum district is the southern most part of Kerala having an area of over $2000 \mathrm{~km}^{2}$. The area can be divided into three distinct physiographic units, highlands, midlands and lowlands. The highlands $(>100 \mathrm{~m})$ characterized by hill ranges with diverse drainage pattern are covered with thick vegetation. The midlands $(10-100 \mathrm{~m})$ characterized by flat topped hills and valleys have lateritic soil cover ( 5 to $10 \mathrm{~m}$ ). The road density in the lowlands is fairly high while in the highlands it is rather poor. The route network related to the present jeep-borne survey is depicted in figure 1.

The area is predominantly constituted by rocks of Precambrian age which include charnockites, garnet-sillimanite gneisses, garnet-biotite gneisses and their migmatitic variants (figure 2). The charnockites contain patches of gneisses with diffused contacts. The gneisses abounding the south and southeast of Trivandrum are highly migmatised. All these rock types are intensely folded and sheared. The pegmatites

GENERALISED GEOLOGICAL MAP OF TRIVANDRUM DISTRICT

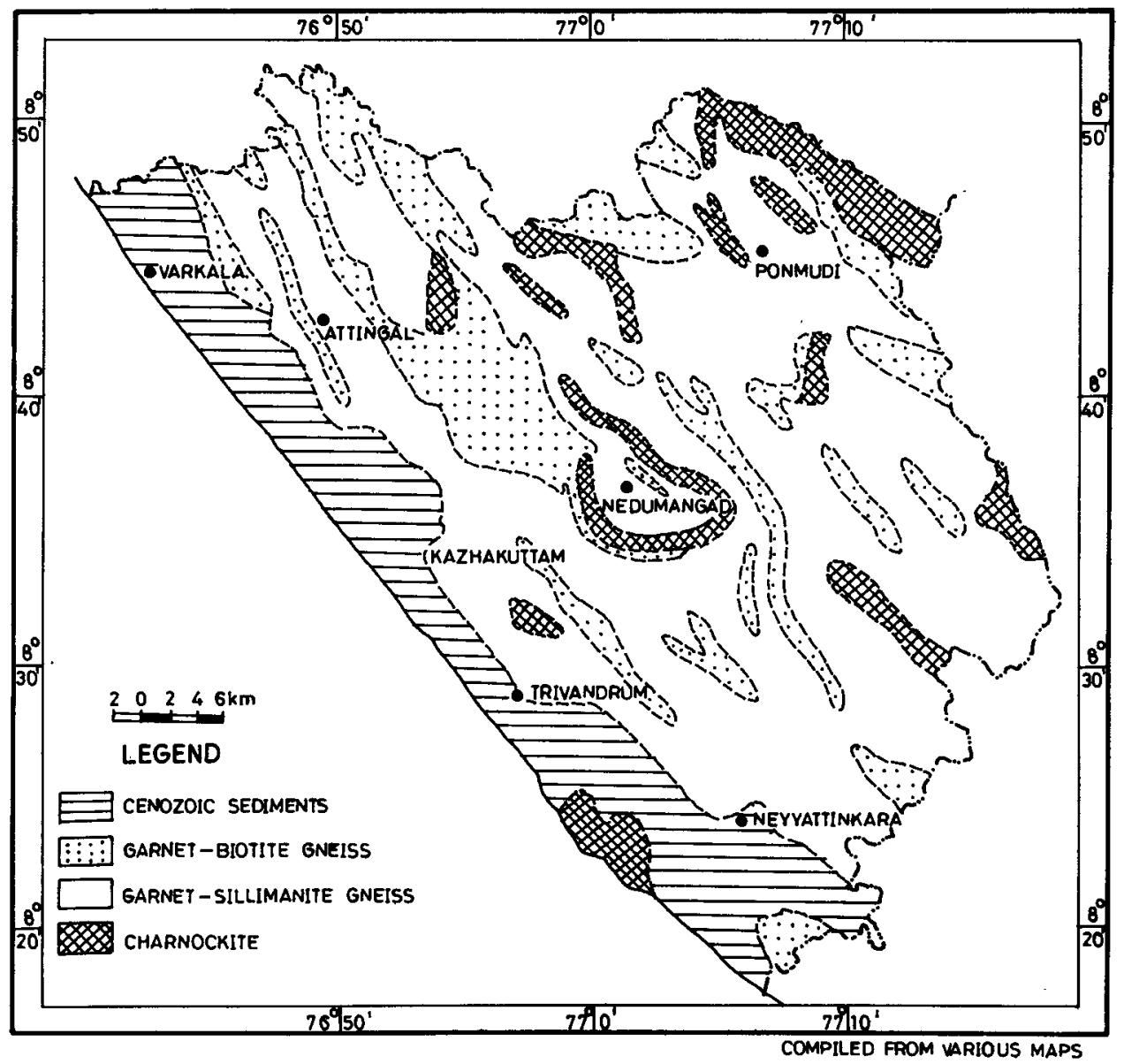

Figure 2. Generalized geological map of the study area. 
which traverse the gneisses at places have fairly high content of monazite veins and disseminations of graphite. Gabbros and dolerites of late Mesozoic to early Cenozoic age traverse the gneisses and granulites.

Tertiary and recent sediments are found mainly in the coastal tracts of this region as narrow NNW-SSE trending bands. The tertiary sediments unconformably overlie the Precambrians which tend to assume and E-W trend as one approaches south towards Trivandrum, and extend into Tamil Nadu with the same trend. These bands are mostly formed of clays and sandstones with older 'teri' sands. Laterites occur in low flat topped ridges and hills, covering the tertiaries and the crystalline rocks between the Western Ghats and the coastal area.

\section{Results and Discussion}

The distribution of the total radioactivity and the individual radioactive elements $\mathrm{Th}, \mathrm{U}$ and $\mathrm{K}$ obtained in counts per sec are presented in figures 3 to 6 . Unlike potassium the distribution pattern of uranium and thorium is similar to that of total radioactivity. The levels of radioactivity over the sedimentary formations vary from low to high, whereas over the crystalline formations, the radioactivity is generally maintained at low levels barring a few anomalous zones. Thus, there is a general relationship between radioactivity and the geology of the area. Based on the radio-elemental distribution, the crystalline-sedimentary contact zones can be inferred. The demarcation of the contact zone can be clearly seen in the total radioactivity map (figure 3 ). Anomalous zones within the sedimentary formations (around Edavai, Kazhakuttam and Kovalam) as well as in the crystalline formations (around Vellanad, Azhikode and Venjaramud) are identified where peak values $>5,000$ CPS in total radioactivity are observed as against the normal background of 1,200 CPS. The laboratory analyses of the samples collected from these anomalous zones are given in table 2. The Precambrian charnockites, gneisses and their migmatitic derivatives are reported to be the parent rocks for radioactive minerals in Kerala and Tamil Nadu (Pichamuthu 1959; Poulose 1956). In the present study, the charnockites and high grade gneisses generally indicate depleted $T h$ and $U$ values with respect to potash values. Similar feature was reported from the granulites of other parts of the Indian Peninsula (Narayanaswamy and Venkatasubramanian 1969; Atal et al 1978) and from other parts of the world (Iyer et al 1984). All the anomalous zones identified within the crystalline formations lie along the sheared flanks of the major plunging antiform. When shearing and crystallization affect the late crystallising minerals, much of the Th is readily released (Constable and Hubbard 1981) and gets concentrated in the acidic intrusives. In addition, intrusive phases of granites and granitic pegmatites are the main sources for monazite (Soman and Nair 1983) in the study area. Hence, monazite is the cause of higher values of thorium. Slightly higher countrates are observed around Neyyar dam, Neyyattinkara, Ponmudi, Madavur etc. where the monazite distribution in the rock is unevenly scattered.

In the midland regions the charnockites and gneisses are lateritized to a considerable extent and high thorium values are observed occasionally at these exposures. These laterites are easily eroded and the disintegrates are sorted and carried by the streams resulting in the concentration of heavy minerals. A slight 


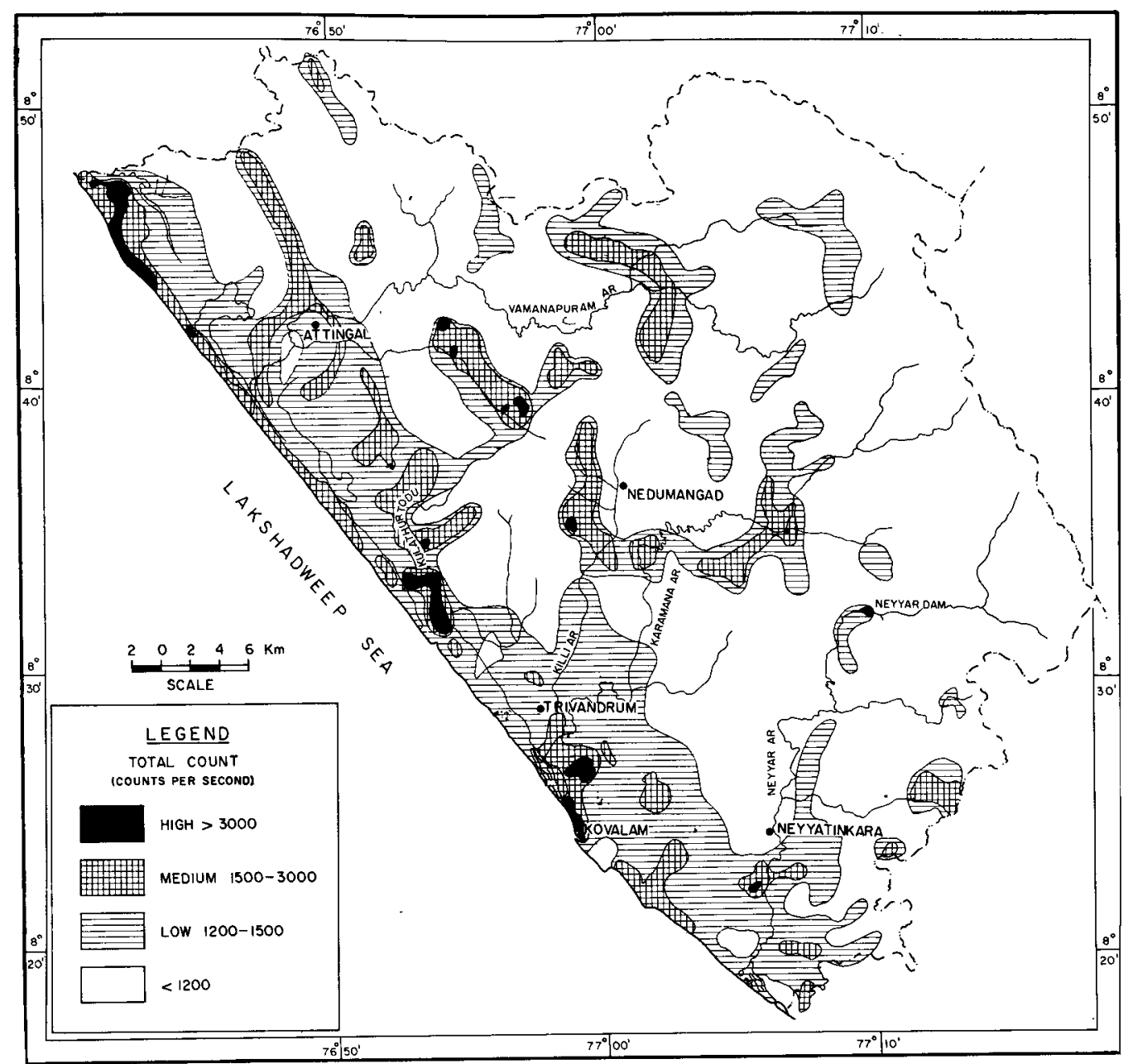

Figure 3. Radiometric map of Trivandrum district showing the distribution of total radio activity (measured with $1853 \mathrm{cc}$ NaI(T1) detector).

increase in the countrate is also one of the features at several places along the terraces of certain rivers and their major tributaries. The laterite cappings are usually enriched in thorium relative to uranium (IAEA 1979) as heavy minerals like zircon and monazite which are resistant to weathering get concentrated in them.

The coastal lands represent a depositional surface in contrast to the midlands and high lands. Enormous amount of material is brought from the higher altitudes by rivers and torrents and the-heavy minerals get separated due to the continuous wave action of the sea forming beach placers along the coast. The Quilon and Warkalli formations exposed to the north around Varkala-Edavai, and to the south around Kovalam have thin bands enriched in heavy minerals. The areas around Kazhakuttom, northwest of Trivandrum, is mainly of sand loams with a zone rich in black sand containing monazite. The higher values recorded along the coastal belt are a reflection of the concentration of radioactive minerals like monazite, zircon 


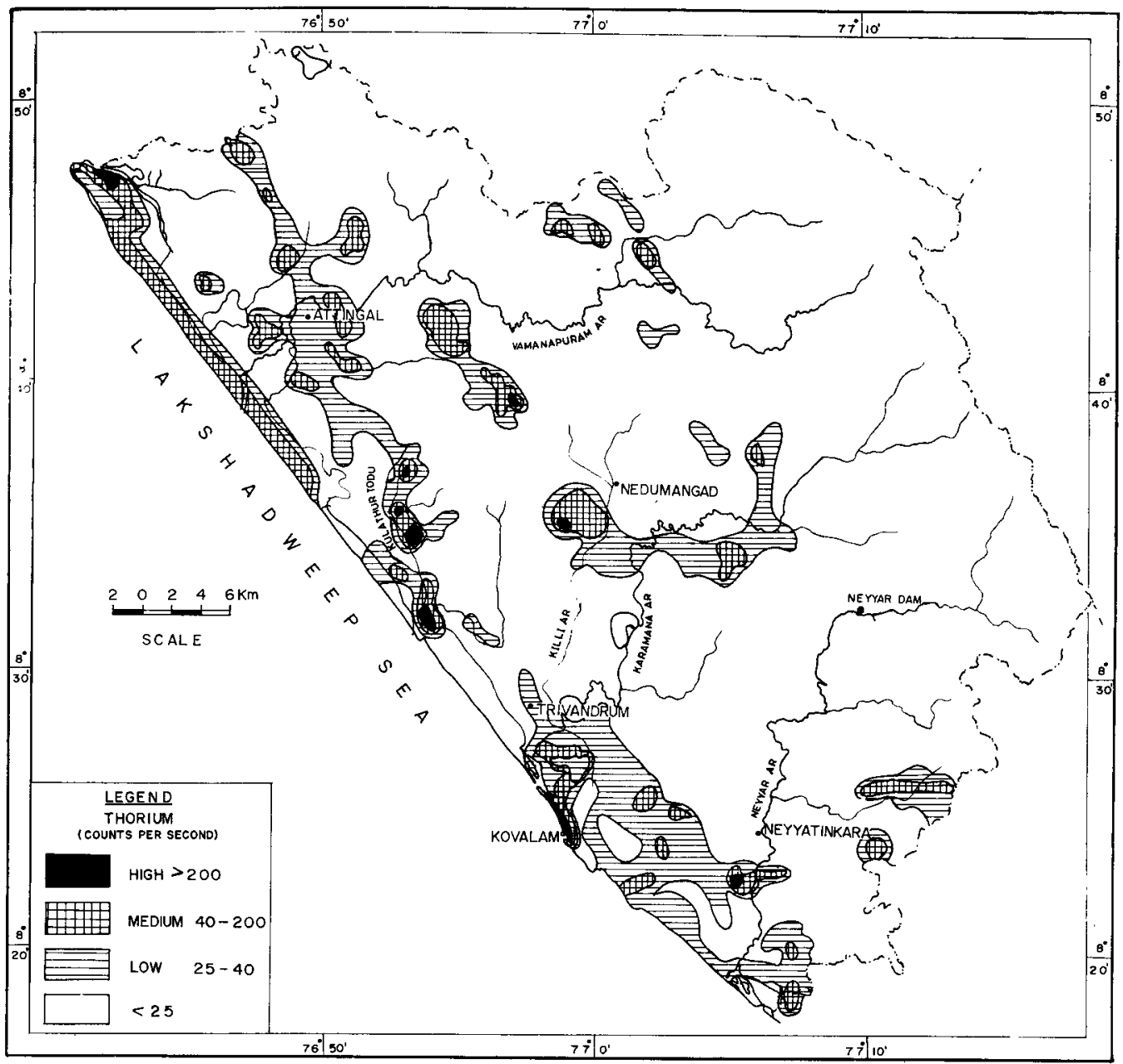

Figure 4. Distribution of radioactivity due to thorium countrate (measured with $1853 \mathrm{cc}$ NaI(T1) detector).

and minor cheralite. These minerals are derivatives of the litho-units forming the high ranges of the region.

Physiography also seems to have played a dominant role in controlling the radioactive mineral distribution. The study area is drained by three major river systems namely Neyyar, Karamana and Vamanapuram Ar. The west flowing drainage system of these rivers had developed in response to coastal upwarping and faulting related to development of continental margin. Subsequently, the drainage pattern and the physiography are largely controlled by the fault/fracture systems. Various evidences suggest that the course of rivers follow the tectonic lineaments. These lineaments also control the occurrence of both acid and basic intrusives which are potential locales of mineralization. The bulk of the sediment load carried down by these rivers and streams might have originated from areas close to these lineaments and weaker zones which host monazite bearing pegmatites. Fluctuation of the sea level over geologic time and the coastal geomorphology are other factors 


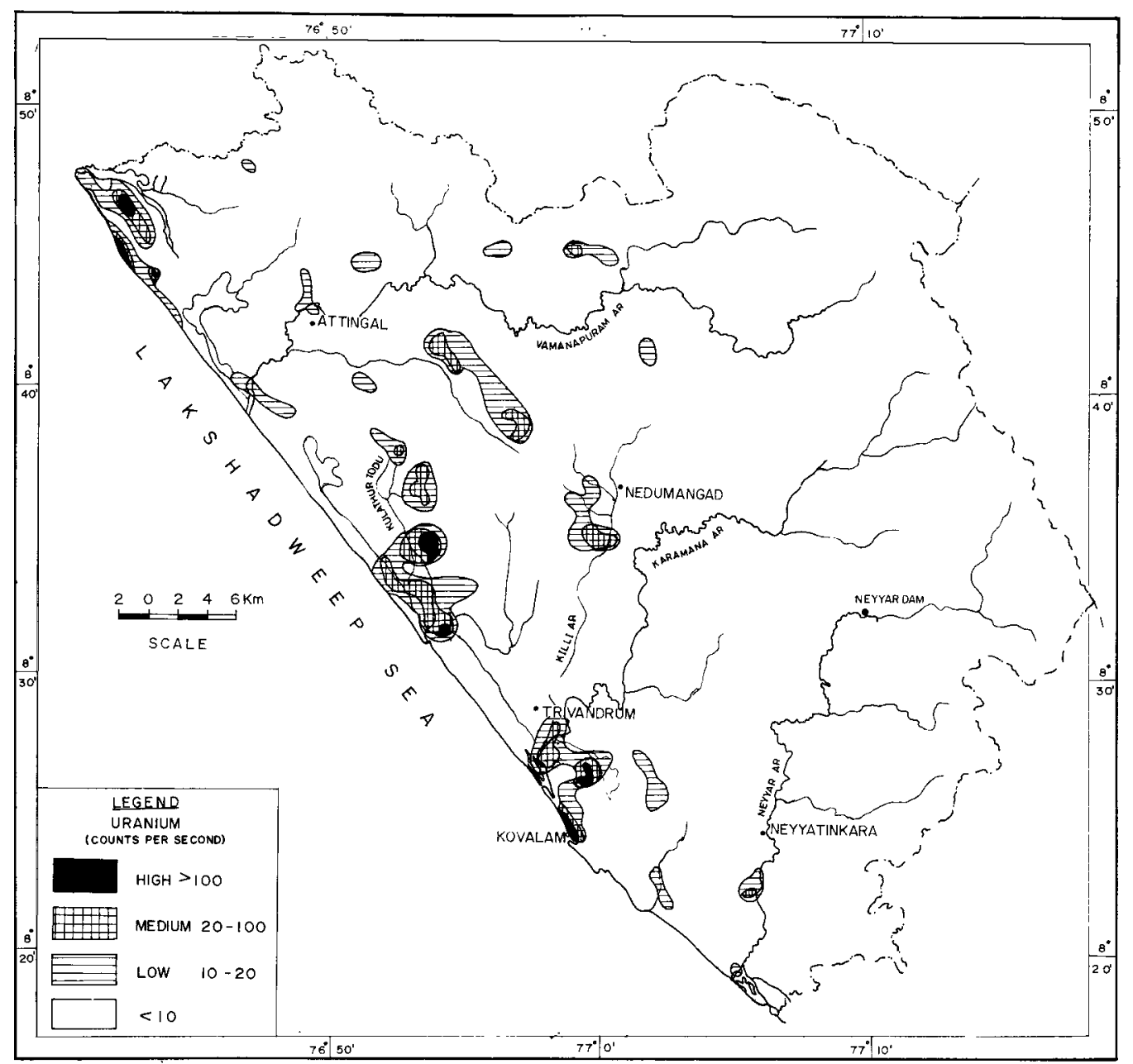

Figure 5. Distribution of radioactivity due to uranium countrate (measured with $185,3 \mathrm{cc}$ NaI(T1) detector).

which have influenced the localization of these radioactive minerals in the coastal belt.

\section{Acknowledgements}

The authors are indebted to Prof. C Karunakaran for encouragement. Our grateful thanks are due to Dr H K Gupta for continued support. The co-operation extended by Mr P V Panchanathan, Dr K Soman and Mr K Vijayakumar is appreciated. The authors also thank the Directors of the Kerala Mineral Exploration Development Project (UNDP), and the Atomic Minerals Division (Hyderabad). 


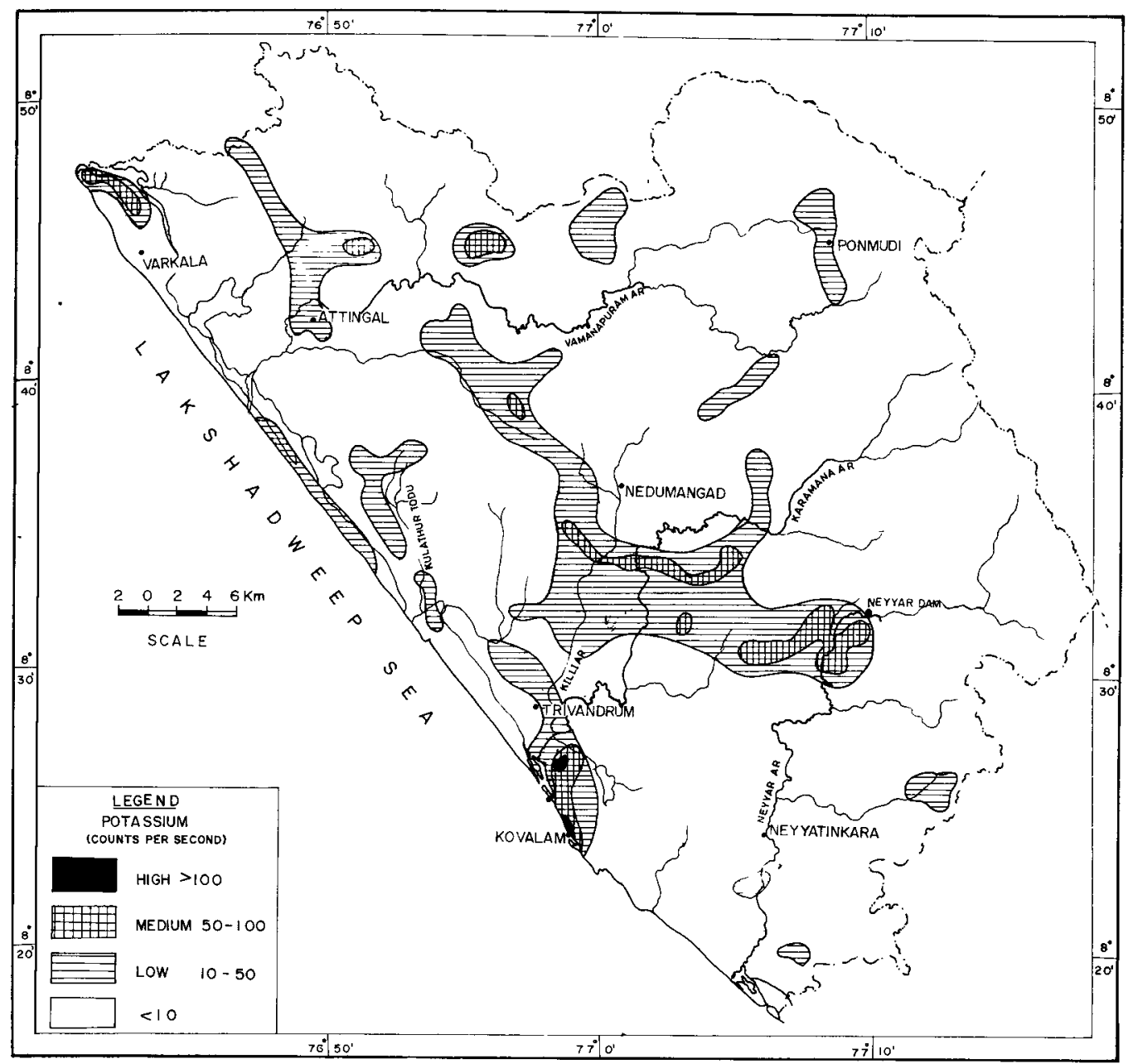

Figure 6. Distribution of radioactivity due to potassium countrate (measured with $1853 \mathrm{cc}$ NaI(T1) detector).

\section{References}

Adams J A S and Gasparini P 1970 Gamma-ray spectrometry of rocks (Elsevier: Amsterdam) 295 Aswathnarayana U 1964 Advancing frontiers in geology and geophysics (eds) A P Subramanian and S Balkrishna (Hyderabad: Indian Geophys. Union) p. 481

Atal B S, Bhalla N S, Lall Y, Mahadevan T M and Udas G R 1978 Archean Geochemistry (eds) B F Windley and S M Naqvi (Elsevier: Amsterdam) p. 205

Bharatwal D S and Vaze G H 1958 Proc. 2nd. Int. Conf. peaceful uses of atomic energy, UN, Geneva 23 156

Brown C J and Dey A K 1975 Mineral and nuclear fuels of the Indian subcontinent and Burma (London: Oxford University Press) p. 415

Constable J L and Hubbard F H 1981 Mineral. Mag. 44409

Darnley A G 1973 Uranium exploration methods, Proc. of a panel: Vienna April 1972 IAEA PL-490/15 p. 67 
Darnley A G 1975 Geol. Surv. Can. Econ. Geol. Rep. p. 21

Foote R S and Humphrey N S 1976 Exploration for uranium ore deposits Proc. Symp. Vienna 1976 IAEA-SM 208/47 p. 17

Ganguly A K, Chhabra A S and Kamath P R 1964 (Govt. of India, AEC Rep. No. AEET Environ) 4156 Grasty R L 1975 Geophysics 40503

IAEA 1979 Tech. rep. series no. 186 p. 99

Iyer S S, Choudhuri A, Vasconcellos M B A and Cordani U G 1984 Contrib. Mineral. Petrol. 8595

Kulkarni V V, Pillai T N V and Ganguly A K 1974 BARC Rep. 702

Lovborg L, Botter J L, Kirkegaard P and Christiansen E M 1976 Exploration for uranium ore deposits, Proc. Symp. Vienna 1976 (Vienna: IAEA) p. 217

Lovborg L, Botter Jensen L, Kirkegaard P and Christiansen E M 1979 Nucl. Inst. Methods 167341

Mahadevan V, Narayanadas G R and Nagaraja Rao N 1958 Proc. 2nd United Nations Int. Conf. on peaceful uses of atomic energy, UN, Geneva 2103

Narayanaswamy R and Venkatasubramanian V S 1969 Geochim. Cosmochim. Acta 331007

Pichamuthu C S 1959 Curr. Sci. 2868

Poulose C V 1956 Bull. Mysore Geol. Assn. 972

Sherrington G H 1977 J. Geochem. Expl. 8325

Soman K and Nair N G K 1983 Trans. Inst. Min. Metall. B92 154

Sunta C M, Nambi K S V, Kathuria S P, Basu A S and David M 1971 BARC Rep. 519 p. 162

Wormald M R and Clayton C G 1976 Exploration for uranium ore deposits, Proc. Symp. Vienna 1976 (IAEA: Vienna) p. 149 